УДК 811.161.2’373.21(477.83)

\title{
СТРУКТУРНІ ТИПИ МІКРОТОПОНІМІВ СЕЛА ВЕЛИКІ ДІДУШИЧІ СТРИЙСЬКОГО РАЙОНУ ЛЬВІВСЬКОЇ ОБЛАСТІ
}

\author{
Любомир Сегін \\ Донбаський державний педагогічний університет \\ Donbas State Pedagogigal University \\ вул. Генерала Батюка, 19, Слов'янськ, 84116, Украӥна \\ lyubomyr13@ukr.net
}

Сегін Л. Структурні типи мікротопонімів села Великі Дідушичі Стрийського району Львівської області

У статті проаналізовано структурні особливості мікротопонімів села Великі Дідушичі Стрийського району Львівської області. У результаті дослідження виявлено складені двослівні, багатослівні та прийменникові мікротопоніми. Серед складених двослівних конструкцій виділено три структурно-словотвірні моделі: прикметник + іменник, числівник + іменник, іменник +іменник. 3'ясовано, що значна частина мікротопонімів села Великі Дідушичі - прийменникові сполуки, які характеризують об'єкт за різними ознаками. У ході роботи здійснено кількісний аналіз мікротопонімів.

Ключові слова: мікротопонім, складені двослівні конструкції, прийменникові сполуки, назви-орієнтири, модель, атрибут, іменник, прикметник.

Сегин Л. Структурные типы микротопонимов села Великие Дедушичи Стрыйского района Львовской области

В статье анализируются структурные особенности микротопонимов села Великие Дедушичи Стрыйского района Львовской области. В результате исследования выявлены составные двухсловные, многословные и предложные микротопонимы. Среди составных двухсловных конструкций выделяются три структурно-словообразовательные модели: имя прилагательное + имя существительное, числительное + имя существительное, имя существительное + имя существительное. Выясняется, что значительная часть микротопонимов села Великие Дедушичи - предложные соединения, которые характеризуют объект по различным признакам. В статье осуществляется количественный анализ микротопонимов.

Ключевые слова: микротопоним, составные двухсловные конструкции, предложные соединения, названия-ориентиры, модель, атрибут, имя существительное, имя прилагательное.

(c) Л. Сегін, 2019. 
Sehin L. Structural types of micro toponyms of Velyki Didushychi of Stryj district of Lvov region

The article presents an analysis of structural features of microtoponyms of Velyki Didushychi village of Stryiskyi district Lviv region. The compound twoword constructions include include three derivative models: adjective+noun, numeral+noun, noun+noun. On the premises of the village there are 48 two-member microtoponyms, among which the largest group is presented by onyms attributed by a possessive adjective ( 25 onyms). The least productive are the microtoponyms distinguished by ordinal numerals containing indication to the ordinal number of a definite denotatum and microtoponyms with the paradigm noun+noun. The group of microtoponyms containing more than two words are represented by six paradigms: numeral+adjective+noun, preposition+adjective+noun, noun+preposition+noun in the genitive case, preposition+noun+noun, preposition+numeral+noun, noun+appellation (genitive case)+proper name (genitive case). It has been distibguished that a significant part of microtoponyms of Velyki Didushychi village are prepositional word combinations which characterize objects on different features (68 units), the most productive prepositions among them being near, behind, on, at.

Key words: microtoponyms, two-word combinations, prepositional word combinations, reference names, pattern, attribute, noun, adjective.

\section{Постановка проблеми та її зв'язок 3 важливими} науковими завданнями. Для другої половини $\mathrm{XX}$ i початку XXI ст. характерне активне вивчення онімів різних регіонів. Не є винятком і Львівщина. На сьогодні досліджено різні види онімів цього краю, зокрема прізвища, прізвиська, гідроніми, ойконіми, топоніми тощо (С. Вербич, 3. Купчинська, М. Наливайко, I. Фаріон, М. Худаш та ін.). Останнім часом помітно зростає інтерес до вивчення мікротопонімів. Названі оніми Львівщини грунтовно проаналізовано у працях Н. Сокіл, О. Проць і Н. Яніцької. Проте поза увагою дослідників залишилися назви малих географічних об'єктів Стрийщини. Дослідження мікротопонімії України $€$ нагальним i невідкладним завданням, оскільки частину мікротопонімів жителі забувають та 3 кожним роком зменшується кількість добрих інформаторів. Об'єктом нашої уваги є мікротопоніми прийменникової та складеної структури села Великі Дідушичі Стрийського району, які не були об'єктом ономастичних досліджень, що зумовлює актуальність статті.

Аналіз останніх досліджень та публікацій. У методику структурного аналізу топонімів, зокрема й мікротопонімів, зробили внесок такі українські вчені, як Д. Бучко, Л. Гумецька, 
Ю. Карпенко, І. Ковалик та ін. Особливості структурних типів мікротопонімів різних регіонів України досліджували Н. Лісняк [Lisniak / Лісняк 2004], О. Лужецька [Luzhetska / Лужецька 2012; Luzhetska / Лужецька 2013], Т. Поляруш [Poliarush / Поляруш 2003], О. Проць [Prots / Проць 2011], Н. Сокіл [Sokil / Сокіл 2008], Н. Яніцька [Yanitska / Яніцька 2012] та ін.

Мета статті - дослідження структурних типів мікротопонімів села Великі Дідушичі Львівської області. Задля досягнення мети розв'язували такі завдання, як-от: 1) проаналізувати особливості прийменникової та складеної структури мікротопонімів названого села; 2) з'ясувати продуктивність моделей творення мікротопонімів.

Матеріалом для дослідження є мікротопонімний матеріал, зібраний шляхом опитування місцевого населення, урезультаті чого зафіксовано 132 складені найменування малих географічних об'єктів.

Виклад основного матеріалу дослідження. У різних джерелах зустрічаємо такі варіанти ойконіма, як Дідушичі Великі, Dieduszyce Wielkie. Сучасна назва Великі Дідушичі закріпилася 3 приходом радянської влади. Із позиції українського мовознавця М. Худаша, первісний варіант назви села Дьдошичи походить від особової назви, тобто від імені Дьдоши́, первинне значення якого 'рід (або піддані) Дьдоша'. Семантичним способом цей патронім перейшов у назву населеного пункту 3 первинним значенням 'населений пункт, який заселяють дњдошичи’. Особова назва Дьдоши́, за словами професора М. Худаша, також похідне утворення, яке виникло внаслідок усічення слов'янського особового власного іменікомпозита Д:дослави́ зі збереженням його препозитивного компонента Дьд[о]- i початкового приголосного -спостпозитивного компонента -слави́ зрощенні Дьдоси́ 3 наступним переходом цього приголосного у приголосний -Ішу сполученні 3 попереднім голосним -о-, який набув значення суфікса -ошú [Khudash / Худаш 1995]. Подібну думку висловлює i А. Купчинський, який, дослідивши назви населених пунктів на -ичі, дійшов висновку, що первісне значення топоформанта -ичі 3'являється в епоху первісно-общинного ладу i вказує на

() Л. Сегін, 2019. 
патронімічний зв'язок між особою предка (виділення наше Л. С.) і нащадками. У ньому поєднується функція походження і родової належності до названої в передсуфіксальній частині особи 3 демінутивною функцією. Таке значення географічних назв на -ичі властиве мовам давніх народів [Kupchynskyi / Купчинський $1981: 215]$.

Зібрані мікротопоніми села Великі Дідушичі за структурою поділяємо на прості (однолексемні), прийменникові, складені двослівні та багатослівні конструкції. На думку Т. Поляруш, складені (двослівні) варіанти назв уживаються в усіх класах топонімів, однак найбільшою мірою вони властиві мікротопонімії [Poliarush / Поляруш : 138]. У межах складених мікротопонімів села Великі Дідушичі виокремлюємо такі структурні типи: 1) двослівні конструкції; 2) прийменникові сполуки (прийменник + лексема); 3) описові структури (три i більше лексем). У межах зібраних двослівних конструкцій другим, опорним словом виступає іменник, а першим прикметник, рідше числівник, а подекуди - сполучення іменника з іменником. За словами Н. Сокіл, механізм творення цих словосполук передбачає складання двох самостійних синтаксичних елементів, які внаслідок топонімізації перетворилися в синтаксично неподільну одиницю [Sokil / Сокіл $2008: 125]$. Атрибутивні сполуки реалізуються двома структурно-словотвірними моделями: 1) прикметник + іменник; 2) числівник + іменник. Прикметникові двочленні конструкції можна поділити на три підгрупи: а) якісний прикметник + іменник; б) відносний прикметник + іменник; в) присвійний прикметник + іменник.

Продуктивною є модель “якісний прикметник + іменник”: Старий Цвинтар (цвинтар), Новий Цвинтар (цвинтар), Стара Церква, Нова Церква, Лиса Гора (берег), Горішна Ферма, Долішна Ферма, Горішний Магазин, Долішний Магазин, Горішна Бригада, Горішний Коне́и (частина села), Долішний Коне́и (частина села), Широка Лінія (дорога). Досить часто такі атрибутивні сполуки виникають шляхом сполучуваності антонімічних прикметників із іменником (Горішний Коне́и, Долішний Коне́u). У зв'язку з цим Ю. Карпенко зазначає, що 
інколи процес своєрідного узагальнення топонімів із географічним терміном спричиняе виникнення строго регламентованих топонімічних найменувань, зокрема численними на Буковині є такі назви частин села, як Горішний Кут і Долішний Кут [Karpenko / Карпенко 1970 : 38]. Якісні ад'єктиви в таких назвах містять вказівку на час виникнення або давність побутування (Старий Цвинтар, Новий Цвинтар, Стара Церква, Нова Церква), розміри об’єкта (Широка Лінія), локалізацію у просторі (Горішний Магазин, Долішний Магазин), інші властивості номінованої мікрореалії (Лиса Гора).

Другий підтип найменувань, супровідним елементом яких слугують відносні прикметники, представлені такими прикладами: Колгоспний Сад, Холєрський Цвинтар (місце), Шкільний Магазин, Вовчиків Гай.

Значну підгрупу найменувань названого села формують мікротопоніми 3 атрибутивними сполуками посесивнорелятивного характеру, у яких атрибутивний компонент ужито у формі присвійного прикметника. Атрибутами мікротопонімів цього підтипу виступають: а) слов'янські відапелятивні особові власні імена чи пізніші прізвиська: Бронькова Калибані, Івасьова Калибані, Батьків Луг, Маџьків Луг, Маџьків Кут, Кіселикові Дуби, Божикова Лінія, Томашова Калибані, Сахурів Луг, Шаріїв Вивіз, Сахурові Зарінки, Сахурова Пилорама (місце); б) антропоніми, що походять від апелятивних означень особи: Жидівський Цвинтар, Польський Цвинтар, Ксьондзова Калибані, Ксьондзова Лінія (дорога), Шевська Дорога, Шевський Куток (сінокіс); в) відойконімні утворення: Човганський Ліс, Сіихівські Стави, Човганська Дорога, Балиџькі Стави, Човганський Луг, Угольнянський Ліс, Малодідушииький Поворот, Малодідушищький Міст. Н. Сокіл зауважує, що всі сполуки з посесивно-релятивними формантами -ів (-ов-а, -ов-о, -ов-е), -ин(а), -ськ- та ін. є відонімними утвореннями [Sokil / Сокіл : 127]. Як зауважує Д. Бучко, мікротопоніми на зразок Ксьондзова Калибані реалізовують антропонімну функцію, бо “власник поля пан мав ім'я і прізвище, але, оскільки він був у селі один, то найкращим засобом його ідентифікації було не 
прізвище, а загальна назва пан, яка власне виконувала у цьому випадку роль оніма" [Buchko / Бучко 2005 : 20].

Окремий підтип формують також мікротопоніми, розрізнювальним елементом яких слугують порядкові числівники, які містять вказівку на порядковий номер певного денотата. Найуживанішими є числівники перший, другий, третій. До цього розряду належать небагато утворень: Перша Шнелька (дорога), Друга Шнелька, Третя Шнелька, Перша Риза (сінокіс), Друга Риза. Виникнення таких формацій може бути зумовлене потребою номінувати кілька однотипних об'єктів, що знаходилися близько один від одного, тому атрибути в цьому разі виконують розрізнювальну функцію [Luzhetska / Лужецька 2012 : 184] або вказують на послідовність появи відповідних географічних об'єктів.

Поодинокі приклади мікротопонімів зафіксовано за моделлю іменник + іменник: Шniu Красни.

Серед зібраного матеріалу виявлено чимало прийменникових конструкцій, які в науковій літературі кваліфікують як назви-орієнтири. За словами Д. Бучка, прийменникові сполуки вказують на розташування “безіменних" de facto географічних реалій щодо інших вагомих i загальновідомих у певній місцевості [Buchko / Бучко 2005 : 20]. “Номінація цих “безіменних” об'єктів у значній мірі залежить від врахування чи неврахування місця знаходження номінатора. При врахуванні місця знаходження номінатора у структурі прийменникової конструкції використовуються прийменники за, nid, перед, від, а при неврахуванні місця знаходження номінатора використовуються прийменники на, в, між, при та ін.” [Buchko / Бучко 2005 : 20]. На думку М. Сороцької, прийменникові конструкції - "це порівняно молодий тип назв, про що свідчить той факт, що той самий об’єкт може бути означений поєднанням різних прийменників з опорним словом, у залежності від місця знаходження номінатора" [Sorotska / Сороцька 2011 : 195].

Прийменникові конструкції - це двослівні сполуки, до складу яких входить прийменник та іменник. Мікротопоніми 3 прийменниками коло/біля виражаються на позначення 
розташування іменованого об'єкта біля іншого примітивного об’єкта або конкретної особи. В аналізованих конструкціях вжито назви об'єктів на позначення рельєфу, рослинності та гідрооб'єктів (Коло Каштана (куток), Коло Ріки (пасовище), Коло Сукілі, Коло Вербини), культурно-історичних реалій (Коло Каплички, Коло Клубу, Коло Церкви, Коло Буфету, Коло Бригади (сінокіс), Коло Труби (сінокіс), Коло Сільради, Коло Школи, Коло Дороги (сінокіс, пасовище), жителів села (Коло Дзіндзі (поле), Коло Тижбірки (зупинка)).

Назви 3 прийменником за містять указівку на те, що означуваний об'єкт знаходиться за іншим примітним об'єктом щодо номінатора [Luzhetska / Лужецька 2013 : 177]. Головним орієнтиром у таких назвах є лексеми, що вказують на рельєф, рослинний покрив, споруди, а також оніми різного походження: За Селом (поле), За Вербинов (поле), За Краснов, За Бригадов (пасовище), За Фермов (поле), За містком, За Париеляциийов (поле, городи), За Трубов (пасовище), За Наров (пасовище), За Церквов, За Дорогов (поле, сінокіс), За Дамбов, За Ровом (пасовище), За Стадіоном (поле). Конструкції з прийменником за номінують переважно поля, пасовища, сінокоси.

Мікротопоніми 3 прийменником $н a$ вказують на місцевість, у якій чи поряд 3 якою локалізований означуваний об’єкт [Podolskaya / Подольская 1983: 50]. Мотивувальною основою таких конструкцій є переважно лексеми на позначення рельєфно-ландшафтних характеристик досліджуваного села: На Берегах (поле), На Випадах (пасовище), На Ланах (село), На Четвертинах, На Стадіоні (місце), На Пекарни, На Париилячії (частина села), На Маслінках (ліс), На Оболоні (сінокіс, поле), На Засукєлю (пасивоще), На Зарощчічу (пасовище, поле), На Партоле (поле), На Піддільничках (поле), На Сукіли (місце), На Тойі, На Пилорамі, На Повороті, На Ставах, На Валах, На Угольну (дорога), На Бригаді (місце), На Бригаду (дорога), На Човгани (дорога).

Малі географічні об'єкти з прийменником у вказують, що денотат розташований на території або в межах просторового охоплення об'єкта орієнтира: $У$ Вербині, У Вільшині (частина сусіднього села), У Соколові, У Зарінках, У Бере́зині, У Кошіи́рі 
(пасовище для коней), У Розтоці, У Красні (ліс), У Ціи́нки (точка), У Мирка (магазин), У Юрка (магазин).

Зрідка фіксуємо найменування з іншими прийменниками, зокрема nid (указує на те, що номінована мікрореалія знаходиться перед іншим географічним об'єктом або нижче від нього), над, понад: Під Липами (цвинтар), Під Мосто́м (місце купання), Під Лісом (сінокіс, пасовище), Під Краснов (сінокіс), Під Високово́льтнов (частина пасовища, сіноксу), Над Ріков (пасовище), Понад Ріку́.

Багатослівні мікротопоніми - це назви, які складаються із трьох і більше лексем. Ці конструкції представлено кількома прикладами: 1) числівник + прикметник + іменник: Перша Панська Лінія (дорога), Друга Панська Лінія, Третя Панська Лінія; 2) прийменник + прикметник + іменник: Біля Тракторної Бригади (сінокіс), Коло Горішного Магазину (зупинка), У Горішнім Кінции́ (частина села), У Долішнім Кінции (частина села); 3 ) іменник + прийменник + іменник у родовому відмінку: Хрест коло Каштана, Кирничка коло Каштана (джерело); 4) прийменник + іменник + іменник: $У$ Кінщи Села (частина села); 5) прийменник + числівник + іменник: У Першій Ризі, У Другій Ризі, У Третій Ризі; 6) іменник + апелятив у Р. в. + іменник власна назва у Р. в.: Поле імені Партоле.

Таблиця 1

Структурні типи мікротопонімів села Великі Дідушичі

\begin{tabular}{|c|c|c|}
\hline Мікротопоніми & К-сть & $\%$ \\
\hline Атрибутивні утворення & 48 & 36,3 \\
\hline Іменникові сполуки & 1 & 0,7 \\
\hline Прийменникові формації & 69 & 52,2 \\
\hline Описові конструкції & 14 & 10,6 \\
\hline Усього & 132 & 100 \\
\hline
\end{tabular}

Висновки та перспективи подальших наукових розвідок. Отже, у мікротопоніміконі села Великі Дідушичі виокремлено такі структурні типи: двослівні конструкції, прийменникові сполуки та багатослівні структури. На території села виявлено 48 двочленних мікротопонімів, найбільшою 3 
яких виявилася група онімів, атрибутом у яких найчастіше виступає присвійний прикметник (25 онімів).

У мікротопонімії села дуже часто використовуються прийменникові конструкції (68 одиниць), найпродуктивнішими серед яких є прийменники коло, за, на, y. У перспективі вбачаємо доцільність дослідження однослівних мікротоопнімів та семантики цих онімів села Великі Дідушичі.

\section{Література}

1. Бучко Д. Анойконіми сіл давнього Любачівського повіту. Mikrotoponimia na pograniczach językowo-kulturowych / redakcja M. Łesiów, M. Olejnik. Lublin : Wyd-wo Uniwersitetu Marii Curie Skłodowskiej, 2005. S. 1723.

2. Карпенко Ю. О. Топонимы и географические термины (вопросы взаимосвязи). Местные географические термины: вопросы географии. Москва : Мысль, 1970. № 81. С. 36-45.

3. Купчинський А. О. Найдавніші слов'янські топоніми України як джерело історико-географічних досліджень (географічні назви на -ичі). Київ : Наук. думка, 1981. 251 с.

4. Лісняк Н. І. Мікротопонімія Західного Поділля: автореф. дис. ... канд. філол. наук : 10.02.01. Львів, 2004. 20 с.

5. Лужецька О. Мікротопоніми складеної структури Бережанщини та Підгаєччини. Рідне слово в етнокультурному вимірі. 2012. С. 181-188. URL : http://nbuv.gov.ua/UJRN/rsev_2012_2012_25

6. Лужецька О. Б. Прийменникові деривати в мікротопонімії ПівденноЗахідного Опілля. Актуальні проблеми філології та перекладознавства: зб. наук. праць. Хмельницький : ХмЦНУ, 2013. Вип. 6. С. 175-182.

7. Подольская Н. В. Типовые восточнославянские топоосновы: словообразовательный анализ. Москва : Наука, 1983. 160 с.

8. Поляруш Т. Структура і функціонування складених назв у різних класах топонімів. Наукові записки Тернопільського державного педагогічного університету. Серія : Мовознавство. Тернопіль : ТДПУ, 2003. Вип. 1. С. 138-142.

9. Проць О. І. Мікротопонімія півночі Львівської області : автореф. дис. ... канд. філол. наук : 10.02.01. Львів, 2011. $21 \mathrm{c.}$

10. Сокіл Н. Мікротопонімія Сколівщини. Львів : Афіша, 2008. 180 с.

11. Сороцька М. Структурні особливості мікротопонімів прийменникової та складеної структури Північної Тернопільщини. Наукові записки Тернопільського начіонального педагогічного університету. Серія: Мовознавство. Тернопіль : ТДПУ, 2011. Вип. 2. С. 191-201.

12. Худаш М. Л. Українські карпатські і прикарпатські назви населених пунктів (утворення від слов'янських автохтонних відкомпозитних скорочених особових власних імен). Київ, 1995. 362 с. 
13. Яніцька Н. Р. Мікротопонімія центральних та східних районів Львівської області : автореф. дис. ... канд. філол. наук : 10.02.01. Львів, 2012. $18 \mathrm{c}$.

\section{References}

1. Buchko D. Anoikonimy sil davnoho Liubachivskoho povitu. Mikrotoponimia na pograniczach językowo-kulturowych / redakcja M. Łesiów, M. Olejnik. Lublin : Wyd-wo Uniwersitetu Marii Curie Skłodowskiej, 2005. S. 17-23.

2. Karpenko Yu. O. Toponimy i geograficheskie terminy (voprosy vzaimosvyazi). Mestnyie geograficheskie terminyi: voprosyi geografii. Moskva : Myisl, 1970. № 81. S. 36-45

3. Kupchynskyi A. O. Naidavnishi slovianski toponimy Ukrainy yak dzherelo istoryko-heohrafichnykh doslidzhen (heohrafichni nazvy na -ychi). Kyiv : Naukova dumka, 1981. $251 \mathrm{c}$.

4. Lisniak N. I. Mikrotoponimiia Zakhidnoho Podillia : avtoref. dys. ... kand. filol. nauk : 10.02.01. Lviv, 2004. $20 \mathrm{~s}$.

5. Luzhetska O. Mikrotoponimy skladenoi struktury Berezhanshchyny ta Pidhaiechchyny. Ridne slovo v etnokulturnomu vymiri. 2012. S. 181-188. URL: http://nbuv.gov.ua/UJRN/rsev_2012_2012_25

6. Luzhetska O. B. Pryimennykovi deryvaty u mikrotoponimii PivdennoZakhidnoho Opillia. Aktualni problemy filolohii ta perekladoznavstva: zb. nauk. prats. Khmelnytskyi : KhmTsNU, 2013. Vyp. 6. S. 175-182.

7. Podolskaya N. V. Tipovyie vostochnoslavyanskie topoosnovyi: slovoobrazovatelnyiy analiz. Moskva : Nauka, 1983. $160 \mathrm{~s}$.

8. Poliarush T. Struktura i funktsionuvannia skladenykh nazv u riznykh klasakh toponimiv. Naukovi zapysky Ternopilskoho derzhavnoho pedahohichnoho universytetu. Seriia : Movoznavstvo. Ternopil : TDPU, 2003. Vyp. 1. S. 138-142.

9. Prots O. I. Mikrotoponimiia pivnochi Lvivskoi oblasti : avtoref. dys. ... kand. filol. nauk : 10.02.01. Lviv, 2011. $21 \mathrm{~s}$.

10. Sokil N. Mikrotoponimiia Skolivshchyny. Lviv : Afisha, 2008. $180 \mathrm{s.}$

11. Sorotska M. Strukturni osoblyvosti mikrotoponimiv pryimennykovoi ta skladenoi struktury Pivnichno Ternopilshchyny. Naukovi zapysky Ternopilskoho natsionalnoho pedahohichnoho universytetu. Seriia: Movoznavstvo. Ternopil: TDPU, 2011. Vyp. 2. S. 191-201.

12. Khudash M. L. Ukrainski karpatski i prykarpatski nazvy naselenykh punktiv (utvorennia vid slovianskykh avtokhtonnykh vidkompozytnykh skorochenykh osobovykh vlasnykh imen). Kyiv, 1995. 362 s.

13. Yanitska N. R. Mikrotoponimiia tsentralnykh ta skhidnykh raioniv Lvivskoi oblasti : avtoref. dys. ... kand. filol. nauk : 10.02.01. Lviv, 2012. 18 s.

Стаття надійшла до редакиії 27.03.2019 p. Прийнята до друку 07.05. 2019 p 